\title{
Differentiation of decidual cells in cultures of rat endometrium
}

\author{
Frances Vladimirsky, Louise Chen, A. Amsterdam, U. Zor and \\ H. R. Lindner
}

Department of Hormone Research, The Weizmann Institute of Science, Rehovot, Israel

\begin{abstract}
Summary. Endometrial scrapings were collected from rat uteri at various times $(0-4$ days) after induction of a decidual reaction by i.p. injection of pyrathiazine hydrochloride $(20 \mathrm{mg} / \mathrm{animal})$ on the 5 th day after a sterile mating. The tissue was dissociated by treatment with trypsin and the cells were cultured as monolayers. The differentiation of decidual cells was followed in these cultures.

Two morphologically distinct cell populations were recognized: (i) dispersed spindle-shaped or stellate cells, and (ii) colonies of closely packed polygonal cells, first apparent after $48 \mathrm{~h}$ in culture. During culture, $\left[{ }^{3} \mathrm{H}\right]$ thymidine was incorporated into the nuclei of both cell types, as indicated by autoradiography. There was an increase in the number of cells in the colonies as culture progressed; most mitotic figures and the highest \% of labelled nuclei were located within the colonies. Bi- and multinucleated cells, which are a characteristic feature of decidual tissue in vivo, appeared in the colonies on the 3rd day of culture and constituted about $60 \%$ of the colony population after 4-5 days. The dispersed cells showed a doubling in nuclear area during 4 days in culture, suggesting the formation of polyploid cells; such cells are prominent in fully differentiated decidual cells in vivo.

The content of prostaglandin $\mathrm{E}$ in the cultured cell, determined by radioimmunoassay, was about 15 -fold higher than that in rat embryo fibroblast cultures grown under similar conditions, and was comparable to the level of prostaglandins found in decidual cells in vivo.
\end{abstract}

\section{Introduction}

Decidual cells arise by proliferation and differentiation from the endometrial stromal cells of the rat uterus, after appropriate stimulation, to form the decidua of pregnancy or the deciduoma of pseudopregnancy (De Feo, 1967; Shelesnyak, Marcus \& Lindner, 1970; Finn, 1971). The morphological and biochemical aspects of decidualization in vivo have been studied in some detail (De Feo, 1967; Shelesnyak et al., 1970; Finn, 1971; Lindner, 1971). It was found that the appearance of bi-, tri- and multinucleated cells (Krehbiel, 1937) and of polyploid nuclear populations (Sachs \& Shelesnyak, 1955; Leroy, Bogaert, Van Hoeck \& Delcroix, 1974) are characteristic features of the decidual cell reaction (DCR). It has also been shown that, during decidualization, the production of prostaglandin $\mathrm{E}$ increases significantly in the uterine tissue (Lindner et al., 1974; Anteby, Bauminger, Zor \& Lindner, 1975).

The deciduoma has a limited life-span (approximately 2 weeks; Lobel, Tic \& Shelesnyak, 1965; De Feo, 1967), but the mechanism of its development and differentiation and the factors determining decidual regression have not been elucidated. In the present study, we report the establishment of an in-vitro system which makes it possible to follow the transformation and differentiation of endometrial stromal cells into decidual cells.

\section{Materials and Methods}

Animals. Wistar-derived rats of the departmental colony were used and vaginal smears from 2-month-old females were examined daily at 08.00-10.00 h. After the establishment of regular 
cycles, pseudopregnancy was induced by mating the animals with vasectomized males on the evening of pro-oestrus. The day on which a copulatory plug or spermatozoa in the vaginal smear were found was designated Day 1 of pseudopregnancy. On Day 5, i.e. the 4th day of a leucocytic smear, the animals were injected with pyrathiazine hydrochloride $(20 \mathrm{mg} / \mathrm{rat}: 10$-[2-(1-pyrrolidyl)ethyl]-phenothiazine hydrochloride; Upjohn, Kalamazoo, Michigan), as described by Shelesnyak \& Kraicer (1961), to induce the formation of deciduomata. The rats were killed by cervical dislocation at various times after the injection. In some experiments, animals were killed on Day 5 without injection of pyrathiazine. The uteri were removed immediately, trimmed of fat and placed in phosphatebuffered saline (PBS), pH 7·2.

Cultures. The deciduomal tissue (approximately $20 \mathrm{mg}$ ), collected by scraping the inner wall of the uterus with a metal spatula, was minced with scissors and incubated for $10-20$ min at $37^{\circ} \mathrm{C}$ with continuous gentle stirring in $15 \mathrm{ml}$ of a solution $(\mathrm{pH} \mathrm{7.4)}$ containing (w/v) $0.25 \%$ trypsin $((1-30 \mathrm{hog}$ pancreas: Nutritional Biochemical Co., Cleveland, Ohio), $0.8 \% \mathrm{NaCl}, 0.04 \% \mathrm{KCl}, 0 \cdot 1 \%$ dextrose, $0.035 \% \mathrm{NaHCO}_{3}$, and $0.2 \mathrm{ml} 0.1 \%$ phenol red solution. When disintegration of the tissue was complete, as judged by visual inspection, the cell suspension was decanted into conical centrifuge tubes and centrifuged at $360 \mathrm{~g}$ for $5 \mathrm{~min}$. The supernatant was discarded and the packed cells were resuspended in Dulbecco's modified Eagle's medium containing $10 \%$ fetal calf serum (FCS: Grand Island Biological Co., Berkely, California). Only trace amounts of trypsin activity remained in the culture medium ( $<0.2 \%$ of original amount), as tested with Azocoll (Calbiochem, Los Angeles, California) as substrate (Mandl, MacLennan \& Howes, 1953). In several experiments trypsinization was terminated by adding soybean trypsin inhibitor (Worthington Biochemical Corporation, Freehold, New Jersey), at a concentration of $1 \mathrm{mg} / \mathrm{ml}$ trypsin solution, calculated to be in excess of the amount needed to inactivate the enzyme (specified potency: $1 \mathrm{mg}$ inhibits $1.7 \mathrm{mg}$ trypsin), but this procedure did not result in improved cell growth. In other experiments, the culture medium was enriched with progesterone $\left(10^{-7} \mathrm{M}\right.$; final concentration) and oestradiol-17 $\left(10^{-9} \mathrm{M}\right)$, either separately or in combination (from Ikapherm, Ramat-Gan, Israel). The steroids were added from ethanolic stock solutions so that the final ethanol concentration in the medium did not exceed $0.01 \%$. In several cases, hydrocortisone acetate $(0.1 \mu \mathrm{g} / \mathrm{ml}$ : Nutritional Biochemical Corp.) and/or insulin ( $5 \mu \mathrm{g} / \mathrm{ml}$ : bovine recrystallized Grade B: Calbiochem) were added to the hormone-enriched culture medium. In a third set of experiments, freeze-dried antiprogesterone serum $(50 \mu \mathrm{g} / \mathrm{ml})$ was added to the culture medium. The properties of this antiserum have been described by Kohen, Bauminger \& Lindner (1975). The cells were counted in a haemocytometer (yield approximately $7 \times 10^{5}$ cells $/ 20$ $\mathrm{mg}$ tissue), and diluted as required for plating. The cultures were seeded at $5.0 \times 10^{4}$ cells per $35-\mathrm{mm}$ Petri dish and incubated in a humidified atmosphere of $5 \% \mathrm{CO}_{2}$ in air at $37^{\circ} \mathrm{C}$. The medium was renewed twice a week.

To determine plating efficiency, $2160-\mathrm{mm}$ Petri dishes were seeded with $1.0 \times 10^{5}$ cells each. Three plates were examined after $24 \mathrm{~h}$ and three plates after each subsequent day of a 7-day incubation. The plates were rinsed twice with PBS and the cells were detached by treatment with $0.9 \mathrm{ml} 0.25 \%$ trypsin and $0.04 \%$ EDTA at $37^{\circ} \mathrm{C}$ for $5 \mathrm{~min}$. FCS $(0.1 \mathrm{ml})$ was added to each plate to inactivate trypsin activity. The cells were suspended by repeated pipetting and counted in a haemocytometer.

Autoradiography. Cells explanted from pyrathiazine-treated rats on Day 6 of pseudopregnancy were cultured and 7.5 $\mu \mathrm{Ci}\left[{ }^{3} \mathrm{H}\right]$ thymidine (sp. act. 40-60 Ci/mmol: Radiochemical Centre, Amersham, U.K.) were added to the cultures after 1, 2, 4 or 5 days of incubation. At $24 \mathrm{~h}$ after addition of the labelled thymidine, the plates (duplicates for each time point) were rinsed three times with $2 \mathrm{ml}$ PBS and fixed for $5 \mathrm{~min}$ with methanol. The plates were then rinsed with twice-distilled water, air dried, coated with Ilford $\mathrm{K}_{5}$ emulsion diluted $1: 1$ with twice-distilled water and incubated at $4^{\circ} \mathrm{C}$ for 1 week in a light-proof container in the presence of a desiccant. The autoradiograms were developed for 4 min with Kodak D-19 developer at $20^{\circ} \mathrm{C}$, fixed with Kodak fixer, and stained lightly with Giemsa diluted 1:10 for 10 min. The plates were photographed and the number of labelled nuclei at each time point was determined by examination of the enlarged photographs.

Morphological examination. Cultures were examined daily with a Zeiss inverted microscope under phase-contrast optics. At various times plates were fixed with methanol for 5 min, rinsed with twice-distilled water and stained with diluted Giemsa solution $(1: 10)$ for $20 \mathrm{~min}$. The stained cells 
were photographed and the nuclear diameters of all cells, whether mononucleate or polynucleate, within a microscopic field were measured on enlarged photographs. Approximate nuclear area $(a)$ was estimated using the formula

$$
a=\pi \frac{\mathrm{d}_{1} \times \mathrm{d}_{2}}{4}
$$

where $\mathrm{d}_{1}$ and $\mathrm{d}_{2}$ are the largest and smallest diameters of the nucleus, respectively (Barlow \& Sherman, 1972). Other estimates, such as the number of colonies/plate, the number of cells/colony and the incidence of polynucleated cells were based on examination of at least 4 different culture dishes, derived from at least two separate experiments.

Determination of prostaglandins and prostaglandin synthetase. Culture plates were rinsed twice with PBS, and the cells suspended in $1.2 \mathrm{ml}$ PBS by scraping with a rubber rod. The cells were homogenized at $4^{\circ} \mathrm{C}$ in a Dounce glass homogenizer. Prostaglandins (PG) of the $E$ type were determined by radioimmunoassay (Bauminger, Zor \& Lindner, 1973) in a portion $(0.5 \mathrm{ml})$ of the homogenate. PG synthetase activity was performed as previously described (Bauminger et al., 1973), using 2 min incubations. PGE concentration and PG synthetase activity were also determined in 4-day-old primary cultures of rat embryo fibroblasts, prepared as described by Huberman \& Sachs (1966). Protein content in the homogenates was determined by the method of Lowry, Rosebrough, Farr \& Randall (1951).

\section{Results}

\section{Growth and differentiation of decidual cells in culture}

Cells derived from endometrial scrapings collected 24 or $48 \mathrm{~h}$ after induction of the deciduoma (Days 6 or 7 of pseudopregnancy, respectively) attached to the bottom of the Petri dishes towards the second half of the first day of culture and formed monolayers. Of the cells originally plated $40-45 \%$ attached to the Petri dishes, and the cell population $\left(4 \times 10^{4}-6 \times 10^{4}\right.$ cells/plate of $60 \mathrm{~mm}$ diameter $)$ remained in a steady state for up to 1 week, after which signs of cellular deterioration appeared. After $24 \mathrm{~h}$ of culture, a homogeneous population of predominantly mononucleate cells was observed (Pl. 1, Fig. 2a). By the 2 nd day of culture two morphologically distinct cell populations could be distinguished: the first consisted of dispersed spindle-shaped or stellate cells and the second of colonies of closely packed polygonal cells (Pl. 1, Fig. 3a; Pl. 2, Fig. 4a). On Days 3-5 there was an apparent increase in cytoplasmic volume, as well as in nuclear area, of the dispersed cells (Pl. 1, Fig. $2 b)$. The nuclei were often irregular in shape and of various sizes, indicating that polyploid cells may have been formed (Pl. 1, Fig. 2b). On Day 2 (Pl. 1, Fig. 3a), there were about 20 colonies/plate, and each colony contained up to 50 cells, which were predominantly mononucleated $(>95 \%)$. The colonies continued to enlarge and full development was obtained by the 4th day of culture, when colonies numbered up to 40/plate, with up to 150 cells/colony (Pl. 2, Fig. 4a). However, even at this time the cells located within colonies comprised only $10 \%$ of the entire cell population. The majority $(60-70 \%)$ of the colony cells at this stage were bi-, tri- or multinucleate (P1. 2, Fig. 4b), the nuclei within one cell being close to each other (Pl. 2, Figs $4 \mathrm{~b}$ and 6 ). The nuclei of the scattered and dispersed cells contained a variable number of pleomorphic dense inclusions (Pl. 2, Fig. 4b). Mitotic figures were numerous, but were located predominantly within the cell colonies (P1. 2, Fig. 5).

A similar pattern of development was obtained with cells explanted on Day 5 of pseudopregnancy from animals not treated with pyrathiazine, but the cells were smaller after $24 \mathrm{~h}$ in culture than those explanted from animals $24 \mathrm{~h}$ after deciduoma induction, and had only a thin rim of cytoplasm (P1. 1, Fig 1a). Cytoplasmic and nuclear volumes of the dispersed cells increased during culture. Early colony formation was observed by $48 \mathrm{~h}$ and on the 4th day of culture there were about 10 colonies/plate. The colonies remained small, however, reaching a maximum size of 30 cells/colony on Day 4, and 30-40\% of the colony cells were bi-, tri- or multinucleated (Pl. 2, Fig. 6).

When cells were explanted from animals $96 \mathrm{~h}$ after deciduoma induction (Day 9), almost no colony formation was observed. There was a higher incidence (15-20\%) of bi- and multinucleate cells 
in the cell population after $24 \mathrm{~h}$ of culture (Pl. 1, Fig. 1b), contrasting with the predominantly mononucleate cell population observed in cells collected from animals $24-48 \mathrm{~h}$ after deciduoma induction and grown for $24 \mathrm{~h}$ in culture. The only noticeable morphological change during culture of these cells was an increase in the cytoplasmic and nuclear volumes, though this was less than that observed in cultures explanted soon after application of the decidualizing stimulus.

\section{Nuclear size}

To obtain an estimate of the incidence and degree of polyploidy in the cell cultures, we compared the nuclear areas of cells in 1-day-old cultures with those of 4-day-old cultures. The mean nuclear area (expressed as $\mu \mathrm{m}^{2} /$ nucleus, irrespective of number of nuclei/cell) of the dispersed cells explanted on Day 6 of pseudopregnancy and maintained for 4 days in culture was double that of the cells examined after the 1 st day in culture $(640 \pm 36$ (S.E.M.) versus $308 \pm 12, P<0.005$ by Student's $t$ test). By contrast, the mean area $\left(\mu \mathrm{m}^{2}\right)$ of individual nuclei in cells located in the colonies was, on average, only insignificantly larger after 4 days of growth than after 1 day of culture (358 \pm 14 versus $308 \pm 12, P<0.05$ ), but even the lower value probably exceeds that characteristic of $2 n$ cells (see below). There was a $75 \%$ increase in the percentage of nuclei ranging from $500-700 \mu \mathrm{m}^{2}$ in area in the 4-day colonies, and a new category of even larger nuclei $\left(700-900 \mu \mathrm{m}^{2}\right)$ appeared (see Text-fig. 1). Many of the cells within the colonies were multinucleated.

The mean nuclear area $\left(\mu \mathrm{m}^{2}\right)$ of the dispersed cells collected from animals on Day 5 (no decidual reaction induced), increased from $220 \pm 8$ on the 1st day of culture to $588 \pm 34$ on the 4th day $(P<0.005)$, while that of cells collected from animals on Day 9 of pseudopregnancy showed a smaller increase, from $432 \pm 18$ to $552 \pm 32(P<0.005)$, respectively.

\section{Thymidine uptake}

The silver grains after autoradiography with $\left[{ }^{3} \mathrm{H}\right]$ thymidine were concentrated over the nuclei; grain density over the cytoplasm did not exceed the background level. The percentage of labelled nuclei was determined separately for the dispersed and colony cells (Table 1). In both cell types thymidine incorporation was high at the start of culture, but declined towards the 5th day in the dispersed cells and after the 2nd day of culture in the colonies (Pl. 1, Fig. 3). Occasionally 2 or 3 labelled nuclei were found within the same cell in a colony (Pl. 1, Fig. 3b).

\section{EXPLANATION OF PLATE 1}

Fig. 1. One-day-old cultures of endometrial cells $(\times 100)$ explanted from rats on (a) Day 5 of pseudopregnancy (without pyrathiazine injection), and (b) Day 9 of pseudopregnancy ( $96 \mathrm{~h}$ after pyrathiazine injection). In Fig. 1 (a) the decidual cells are mononucleate and the small nuclei are surrounded by only a thin rim of cytoplasm (cf. Pl. 2, Fig. 6). The cells in Fig. 1(b) have larger cell bodies and larger nuclei, and some of them are binucleate (Fig. 1b).

Fig. 2. Decidual cells $(\times 100)$ seen after (a) 1 day and (b) 4 days in culture. Endometrial cells were explanted $24 \mathrm{~h}$ after i.p. injection of pyrathiazine given on Day 5 of pseudopregnancy. The cultures consisted of dispersed cells, shown here, and cell colonies, illustrated in Figs 4-6. The nuclei of the predominantly mononucleate cells are relatively small and homogeneous after 1 day in culture (Fig. 2a) and large and irregularly shaped after 4 days (Fig. 2b). Note also the marked increase in cy toplasmic volume of the cells during 4 days in culture. Giemsa staining.

Fig. 3. Autoradiograms of decidual cells, explanted on Day 6 of pseudopregnancy ( $24 \mathrm{~h}$ after pyrathiazine injection) and exposed to $\left[{ }^{3} \mathrm{H}\right]$ thymidine for $24 \mathrm{~h}$ in culture. Black arrows, labelled nuclei; open arrows, unlabelled nuclei. (a) View of cells $(\times 50)$ labelled during the 2 nd day in culture. There is a small colony of predominantly mononucleate cells, most of which have nuclei densely covered with silver grains. A high proportion of nuclei of the dispersed cells are also labelled. (b) Colony of cells ( $\times 110)$ labelled during the 4 th day of culture. Many of the nuclei are unlabelled, but the cells containing 2-3 nuclei are all labelled (black arrows). (c) Part of a large colony of cells $(\times 110)$ labelled during the 5th day of culture. Few nuclei within the colony are labelled. 
PLATE 1

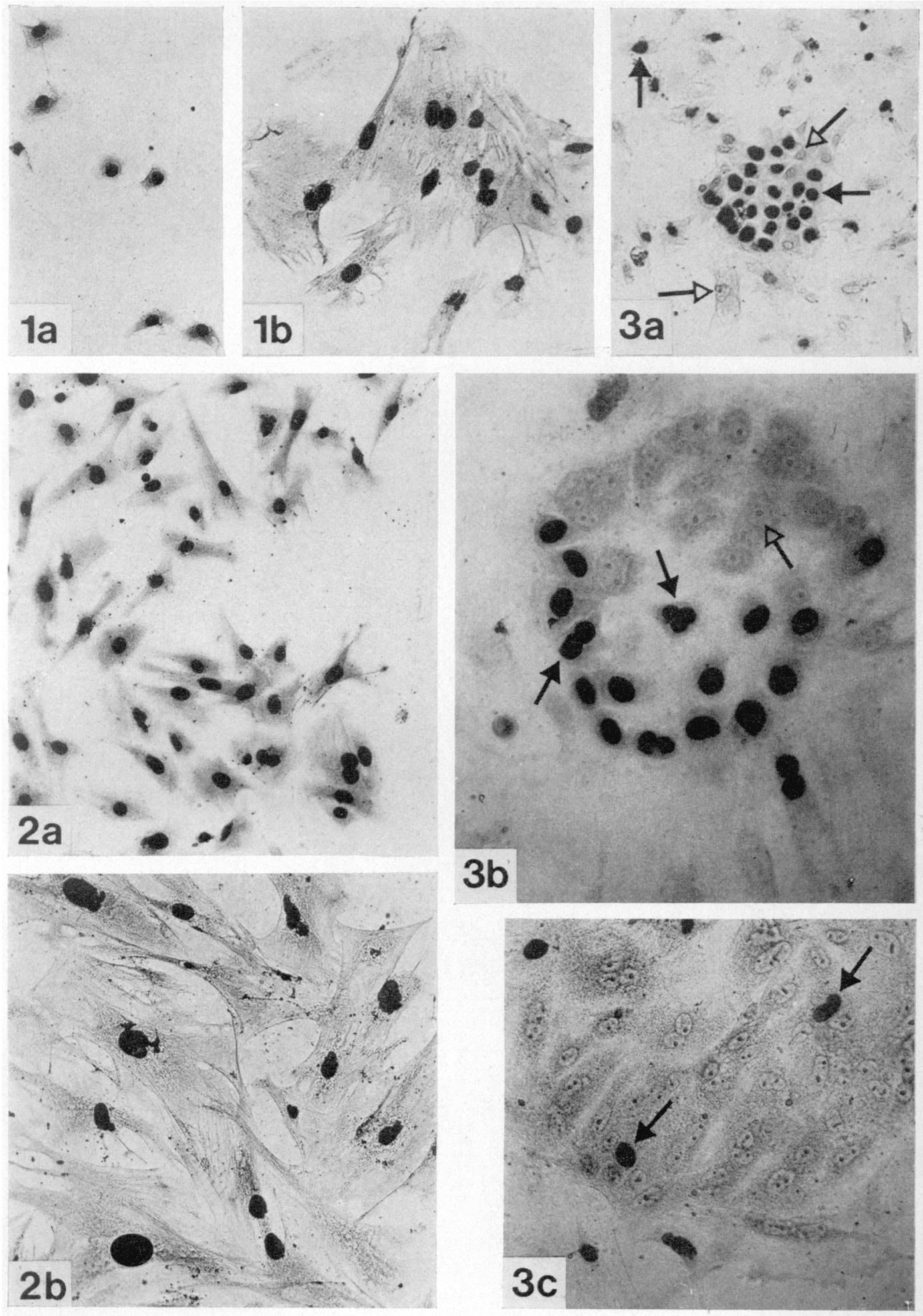

(Facing p. 64) 
PLATE 2
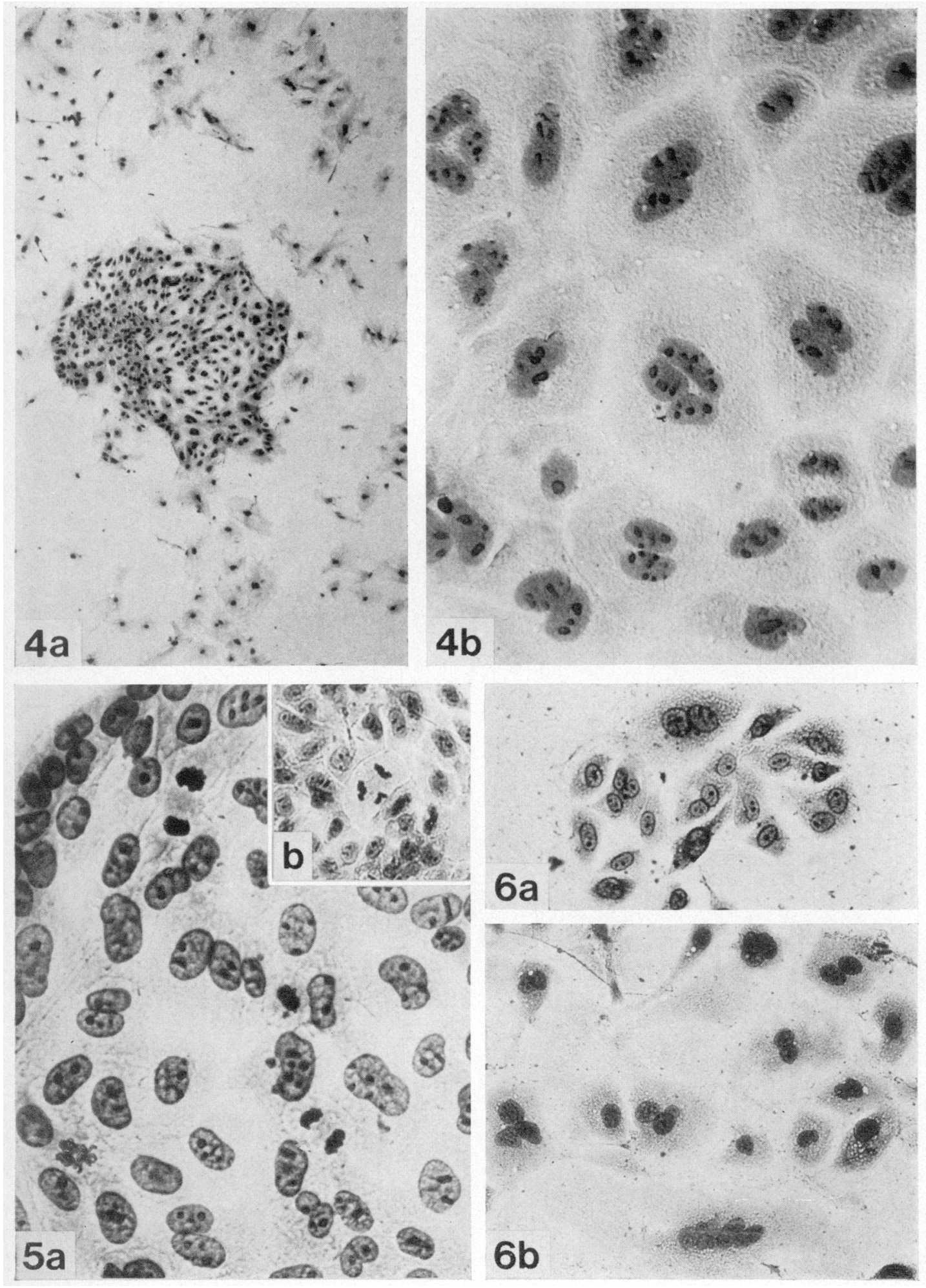

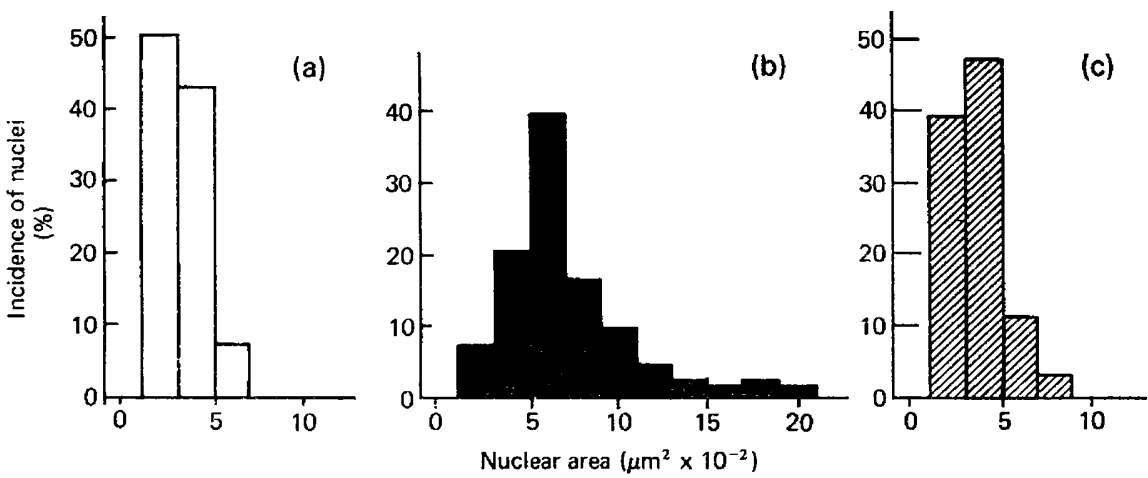

Text-fig. 1. Frequency distribution of nuclear area in rat decidual cells. (a) Dispersed cells from 1-day-old cultures; (b) dispersed cells from 4-day-old cultures: (c) cells located within colonies of 4-day-old cultures. Celis were explanted on Day 6 of pseudopregnancy ( $24 \mathrm{~h}$ after pyrathiazine injection). Nuclear area was calculated for 200 nuclei in each group, as described in 'Materials and Methods'.

Table 1. Thymidine incorporation by rat decidual cell cultures

\begin{tabular}{ccc}
\hline \multirow{2}{*}{ Day of culture } & \multicolumn{2}{c}{$\%$ Labelled nuclei (mean \pm S.E.M.)* } \\
\cline { 2 - 3 } & Dispersed cells & Colonies \\
\hline 1 & $30 \pm 1$ & - \\
2 & $33 \pm 3$ & $69 \pm 3$ \\
4 & $25 \pm 2$ & $37 \pm 5$ \\
5 & $14 \pm 2$ & $23 \pm 7$ \\
\hline
\end{tabular}

* For 6 different fields containing dispersed cells on duplicate plates, each field containing at least 150 cells; or for 5-10 colonies on duplicate plates, total count 320 to 530 cells.

\section{Effect of hormone supplementation}

In an effort to increase the rate of division and prolong the life-span of decidual cells in culture, the culture medium was supplemented with near-physiological concentrations of oestrogen $\left(10^{-9} \mathrm{M}\right)$ and progesterone $\left(10^{-7} \mathrm{M}\right)$, the two hormones which play a role in the induction of the decidual reaction and the maintenance of decidual cells in vivo (Finn, 1971 ; Nimrod, Ladany \& Lindner, 1972; Psychoyos, 1973; Glasser \& Clark, 1975). Hydrocortisone and insulin, which have been found to enhance cell growth and differentiation in other systems (Gospodarowicz \& Moran, 1974), were also added,

\section{EXPLANATION OF PLATE 2}

Fig. 4. Decidualizing endometrium was explanted on Day 7 of pseudopregnancy, $48 \mathrm{~h}$ after pyrathiazine injection, and grown as monolayers for 4 days. (a) Low power view $(\times 25)$ : many of the cells are dispersed throughout the culture plate, while others are closely packed, forming a colony in the centre of the field. (b) Part of the colony at higher magnification $(\times 270)$, showing polygonal cells, containing 1-3 nuclei each. Multiple nuclei are usually closely apposed to each other and contain several distinct darkly staining areas, which are often distributed in a similar pattern in sister nuclei.

Fig. 5. Part of a decidual cell colony derived from endometrium explanted on Day 6 of pseudopregnancy, 24 $\mathrm{h}$ after pyrathiazine injection and cultured for 4 days. (a) Several stages of mitosis (arrows) can be observed within the colony $(\times 270)$. (b) Tri-polar mitotic figure (arrow) located within a second colony $(\times 120)$.

Fig. 6. Endometrial cells were explanted on Day 5 of pseudopregnancy from untreated animals and maintained in culture for 4 days. (a) Typical small colony containing polygonal cells with abundant cytoplasm and 1-3 nuclei. (b) Part of a larger colony containing up to 5 nuclei/cell, Compare with PI. 1, Fig. 1 (a). $\times 120$. 
either separately or in combination with the gonadal steroids, to the culture medium. Enrichment of the medium with these factors did not enhance the rate of cell division in any culture. Furthermore, addition to the medium of specific antiserum to progesterone at a concentration adequate to bind $1.6 \times 10^{-9} \mathrm{M}$-progesterone did not have any adverse effect on the growth of the decidual cell cultures.

\section{Prostaglandin production}

Deciduomal cells derived from endometrial scrapings collected on Day 6 of pseudopregnancy and cultured for 4 days had a concentration (ng/mg protein) of PGE which was 12-15 times higher (19.6 \pm 0.62 (S.E.M.), $n=9$ culture plates/group) than that in fibroblasts $(1.35 \pm 0.20, n=9)$. Prostaglandin synthetase activity (ng PGE/mg protein $/ 2 \mathrm{~min}$ ) in the decidual cells $(58 \pm 2 \cdot 1, n=9$ ) was 5-6-fold that found in the fibroblasts $(10 \cdot 6 \pm 1 \cdot 6, n=9)$. The concentration of PGE and PG synthetase activity in cells explanted from animals 48, 72 and $96 \mathrm{~h}$ (Days 7-9) after deciduomal induction and cultured for 4 days were equally high.

\section{Discussion}

The culture system described in this paper permits study in vitro of the transformation of endometrial cells into decidual cells. The endometrial cells were explanted at three different stages of development: (i) on Day 5 of pseudopregnancy, so that decidual induction and differentiation took place in vitro; (ii) during the early stages of the decidual reaction, $24-48 \mathrm{~h}$ after induction in vivo; and (iii) fully differentiated decidual cells collected $96 \mathrm{~h}$ after induction of the decidual reaction in vivo. Under all these experimental conditions, the cultured cells displayed several features characteristic of decidual cells, e.g. polynucleation, polyploidy, and a high rate of PGE formation. In addition, electron microscope examination revealed an abundance of thin filaments in the cytoplasm (unpublished), similar to those observed in decidual cells in vivo (Tachi, Tachi \& Lindner, 1970).

Polynuclear decidual cells could arise either through fusion of diploid cells (Dupont, Duluc \& Mauer, 1971) or through karyokinesis without subsequent cell division (Ansell, Barlow \& McLaren, 1974). Several of the present observations lend support to the latter view. Nuclei lying within the same cell were closely apposed and resembled each other with respect to number and size of inclusions (nucleoli and possibly heterochromatin; Pl. 2, Fig. 4b). Furthermore, after exposure to $\left[{ }^{3} \mathrm{H}\right]$ thymidine, no 'hybrid' cells containing both labelled and unlabelled nuclei were observed, contrary to expectation if cell fusion were involved. There were, however, indications of imperfect karyokinesis, such as the observation of a tripolar mitotic figure (PI. 2, Fig. 5b) and of many multinucleate cells containing an odd number of nuclei ( 3 or 5). Synchronous division of nuclei lying within the same cell (Watson, 1971) should have resulted in an even number of nuclei.

Although the cultured cells were actively engaged in DNA replication, as indicated by nuclear incorporation of $\left[{ }^{3} \mathrm{H}\right]$ thymidine and the appearance of scattered colonies, there was no increase in the number of cells during the 7-day incubation. In vivo, only cells located in the periphery of the deciduoma divide, whilst the fully differentiated polyploid cells at its centre appear incapable of division (Lobel et al., 1965; Tachi et al., 1970; Finn, 1971). In our cultures, the highest percentage of thymidinelabelled nuclei and all the observed mitotic figures occurred within the colonies, which thus resemble the peripheral decidual zone. In the dispersed cell population, continued thymidine incorporation in the absence of detectable mitotic activity suggested the emergence of polyploidy, probably through endoreduplication (cf. Ansell et al., 1974; Leroy et al., 1974). This view is supported by the observation that the mean nuclear area in these cells more than doubled during the first 4 days of culture. Nuclear size was shown to be strongly correlated with degree of ploidy (Barlow \& Sherman, 1972). The increase in apparent polyploidy with day of culture, as indicated by the shift in the distribution of nuclear size, agreed well with the changes in DNA content of deciduoma cells observed at comparable times after induction of the decidual reaction in vivo (Leroy et al., 1974). 
The similar results with material from untreated animals on Day 5 of pseudopregnancy suggests that the induction of the decidual reaction, as well as the differentiation of endometrial stromal cells into decidual cells, can be obtained in vitro. It is possible that in these experiments mechanical trauma during the collection of endometrial cells triggered the decidual reaction, as it will in vivo (Loeb, 1907).

In vivo, the availability of progesterone is mandatory for the induction of the decidual reaction and the maintenance of the decidual tissue (De Feo, 1967; Finn, 1971; Psychoyos, 1973; Glasser \& Clark, 1975). It is therefore surprising that decidual cells were formed and maintained in culture without supplementing the medium with this hormone. Our medium included $10 \%$ FCS which gave a final concentration of approximately $10^{-10} \mathrm{M}$-progesterone, as determined by radioimmunoassay (data not shown), but enrichment of the medium with $10^{-7} \mathrm{M}$-progesterone did not enhance the rate of cell division of the cultures, and a specific antiserum to progesterone did not impair the formation and growth of decidual cells in vitro. The apparent discrepancy remains unexplained. Oestrogen, in addition to progesterone, is required in vivo for induction of the decidual reaction by the blastocyst or by atraumatic stimuli (De Feo, 1967; Finn, 1971; Nimrod et al., 1972; Psychoyos, 1973; Glasser \& Clark, 1975). The lack of an oestrogen requirement for triggering the decidual reaction in vitro might be explained by the cell damage inherent in the collection and dissociation of the endometrial cells. We have not been able to maintain decidual cell cultures for more than 1 week. It is possible that this is due to an inherent life-span of these cells. Alternatively, the hormonal support in the medium may not have been optimal. However, the establishment of an in-vitro model of the decidual transformation should facilitate mechanistic analysis of this process.

We are grateful to Mr S. Joseph for devoted animal care; to Dr E. Huberman (Department of Genetics, Weizmann Institute of Science), for supplying primary cultures of rat embryo fibroblasts for the prostaglandin assays, and to Dr P. W. O'Connell (Upjohn Co.) for the pyrathiazine hydrochloride. H.R.L. is the Adlai Stevenson III Professor of Endocrinology and Reproductive Biology at the Weizmann Institute of Science. This work was in partial fulfilment of the requirements for the M.Sc. degree of the Graduate School of the Weizmann Institute of Science to F.V. and was supported by the Ford Foundation and the Population Council, New York.

\section{References}

Ansell, J.D., Barlow, P.W. \& Mclaren, A. (1974) Binucleated polyploid cells in the decidua of the mouse. J. Embryol. exp. Morph. 31, 223-227.

ANTEBy, S.O., BaUminger, S., ZoR, U. \& Lindner, H.R. (1975) Prostaglandin synthesis in decidual tissue of the rat uterus. Prostaglandins 10, 991999.

Barlow, P.W. \& Sherman, M.I. (1972) The biochemistry of differentiation of mouse trophoblast: studies on polyploidy. J. Embryol. exp. Morph. 27, 447-465.

Bauminger, S., Zor, U. \& Lindner, H.R. (1973) Radioimmunological assay of prostaglandin synthetase activity. Prostaglandins 4, 313-324.

DE FEO, V.J. (1967) Decidualization. In Cellular Biology of the Uterus, pp. 191-290. Ed. R. M. Wynn. Appleton-Century-Crofts, New York.

DuPont, H., Duluc, J.A. \& MAYER, G. (1971) Evolution cytologique et genése de la polyploidie dans le déciduome experimental chez la ratte en gestation unilatérale. C. r. hebd. Séanc. Acad. Sci., Paris 272, 2360-2363.

Finn, C.A. (1971) The biology of decidual cells. $A d v$. Reprod. Physiol. 15, 1-26.
Glasser, S.R. \& ClaRK, J.H. (1975) A determinant role for progesterone in the development of uterine sensitivity to decidualization and ova-implantation. In Developmental Biology of Reproduction, pp. 311-345. Eds C. L. Markert \& J. Papconstantinov. Academic Press, New York.

Gospodarowicz, D. \& Moran, J.S. (1974) Stimulation of division of sparse and confluent $3 \mathrm{~T} 3$ cell population by a fibroblast growth factor, dexamethasone and insulin. Proc. natn. Acad. Sci. U.S.A. 71, 4584-4588.

Huberman E. \& Sachs, L. (1966) Cell susceptibility to transformation and cytotoxicity by the carcinogenic hydrocarbon benzo-a-pyran. Proc. natn. Acad. Sci. U.S.A.56, 1123-1129.

Kohen, F., Bauminger, S. \& Lindner, H.R. (1975) Preparation of antigenic steroid-protein conjugates. In Steroid Immunoassay, pp. 11-32. Eds E. H. D. Cameron, G. S. Hillier \& K. Griffiths. Alpha Omega Publishing Ltd, Cardiff.

KrehbieL, R.H. (1937) Cytological studies of the decidual reaction in the rat during early pregnancy and in the production of deciduomata. Physiol. Zool. 10, 212-234. 
Leroy, F., Bogaert, C., Van Hoeck, J. \& Delcroix, C. (1974) Cytophotometric autoradiographic evaluation of cell kinetics in decidual growth in rats. $J$. Reprod. Fert. 38, 441-449.

LINDNER, H.R. (1971) Choice of animal model for study of ovum implantation. In The Use of Non-human Primates in Research on Human Reproduction, pp. 93-99. Eds E. Diczfalusy \& C. C. Standley. Karolinska Sjukhuset, Stockholm.

LindNer, H.R., Zor, U., Bauminger, S., Tsafriri, A., LAMPRECHT, S.A., КосH, Y., ANTEBI, A.S. \& Schwartz, A. (1974) Use of prostaglandin synthetase inhibitors in analyzing the role of prostaglandins in reproductive physiology. In Prostaglandin Synthetase Inhibitors, pp. 271-287. Eds H. J. Robinson \&J. R. Vane. Eaven Press, New York.

Lobel, B.L., Tic, L. \& Shelesnyak, M.C. (1965) Studies on the mechanism of nidation. VII. Histochemical analysis of decidualization in the rat. Part I. Framework: oestrous cycle and pseudopregnancy. Acta endocr., Copenh. 50, 452-468.

LoEB, L. (1907) Wounds of the pregnant uterus. Proc. Soc. exp. Biol. Med. 4,93-94.

Lowry, O.H., Rosebrough, N.J., Farr, A.L. \& RaNDALL, R.J. (1951) Protein measurement with the Folin phenol reagent. J. biol. Chem. 193, 265-275.

Mandl, I., Maclennan, J.D. \& Howes, E.L. (1953) Isolation and characterization of proteinase and collagenase from cl. histolyticum. J. clin. Invest. 32, 1323-1329.

Nimrod (Zmigrod), A., LADANY, S. \& Lindner, H.R. (1972) Perinidatory ovarian oestrogen secretion in the pregnant rat, determined by gas-chromatography with electron capture detection. J. Endocr. 53, 249-260.

Psychoyos, A. (1973) Hormonal control of ovaimplantation. Vitams Horm. 31, 201-256.

SACHS, L. \& SHELESNYAK, M.C. (1955) The development and suppression of polyploidy in the developing and suppressed deciduoma in the rat. J. Endocr. 12, 146-161.

Shelesnyak, M.C. \& Kraicer, P.F. (1961) A physiological method for inducing experimental decidualization of the rat uterus: standardization and evaluation.J. Reprod. Fert. 2, 438-446.

Shelesnyak, M.C., MARCUS, G.J. \& LindNER, H.R. (1970) Determination of the decidual reaction. In Ova-implantation, Human Gonadotrophins and Prolactin, pp. 118-129. Eds P. O. Hubinont, F. Leroy, C. Robyn \& P. Leleux. Karger, Basel.

TACHI, S., TACHI, C. \& LINDNER, H.R. (1970) Ultrastructural features of blastocyst attachment and trophoblastic invasion in the rat. J. Reprod. Fert. 21, 37-56.

WATSON, J.W. (1971) The regulation of DNA synthesis in eukaryotes. Adv. Cell. Biol. 2, 1-46.

Received 28 May 1976 